\title{
Kreacjonizm i ewolucjonizm z punktu widzenia modelu poziomów analizy - z odwołaniem do fragmentów twórczości Piotra Lenartowicza SJ
}

\author{
Piotr Bylica \\ Zakład Logiki i Metodologii Nauk, Instytut Filozofii, Uniwersytet Zielonogórski \\ al. Wojska Polskiego 69, 65-762 Zielona Góra \\ p.bylica@ifil.uz.zgora.pl•ORCID 0000-0001-6668-6170
}

\begin{abstract}
Streszczenie
Model poziomów analizy (MPA) wyróżnia pięć rodzajów twierdzeń opisowych o rzeczywistości dzieląc je przede wszystkim pod względem stopnia ich empirycznej testowalności. Celem tego artykułu jest wskazanie przy użyciu MPA odmian kreacjonizmu i ewolucjonizmu oraz twierdzeń w nich zawartych. Pozwoli to ocenić różne ich odmiany w kontekście prób godzenia nauki i religii oraz problemu naukowości poszczególnych twierdzeń kreacjonizmu i ewolucjonizmu. W tekście zostaną wykorzystane odwołania do wypowiedzi Piotra Lenartowicza, który zabierał ważny głos w dyskusji między omawianymi stanowiskami. Pozwoli to wskazać przy pomocy MPA zarówno trafne spostrzeżenia Lenartowicza dotyczące światopoglądowo-filozoficznych czynników w nauce, jak i te, które trudno utrzymać, gdy uwzględni się ustalenia współczesnej filozofii nauki na temat relacji między obserwacją a teorią i czynnikami filozoficznymi. Szczególnie MPA pozwoli łatwiej dostrzec, że teistyczne przekonania filozoficzno-teologiczne mające wynikać niejako z nieuprzedzonej obserwacji świata pełnią w rzeczywistości rolę założeń, które wpływają na to, co dostrzega się w świecie jako fakty.
\end{abstract}

\section{Stowa kluczowe}

kreacjonizm, ewolucjonizm, poziomy analizy, Piotr Lenartowicz SJ

\section{Wstęp}

W bogatej literaturze poświęconej dyskusji kreacjonizmu i ewolucjonizmu stanowiska te są rozumiane różnorako. Celem tego artykułu jest wskazanie ich odmian oraz twierdzeń w nich zawartych, gdy ujmie się je pod względem roli czynników empirycznych w tych stanowiskach. Może to przyczynić się do rozjaśnienia aspektów tej dyskusji związanych głównie z problemami relacji nauki i religii (teizmu chrześcijańskiego), jak i naukowości poszczególnych twierdzeń kreacjonizmu i ewolucjonizmu. Szczególnie zagadnienie zgodności ewolucjonizmu z religijnym ujęciem rzeczywistości wymaga uwzględnienia naczelnej cechy nauki, jaką jest związek z danymi empirycznymi i określonymi twierdzeniami filozoficznymi oraz roli elementów empirycznych po stronie religii. Tymczasem istotą większości deklaracji mówiących o braku konfliktu nauki i religii jest często negowanie wagi religijnych twierdzeń o charakterze empirycznym 
i pomijanie roli, jaką empirycznie nietestowalne twierdzenia filozoficzne odgrywaja $\mathrm{w}$ nauce.

Model poziomów analizy (MPA) wyróżnia pięć rodzajów twierdzeń opisowych o rzeczywistości, dzieląc je przede wszystkim pod względem stopnia ich empirycznej testowalności. Dodatkowymi kryteriami pozwalającymi uszczegółowić ten podział są też ogólność oraz ważność danego typu twierdzeń w nauce. Używając tego modelu, ujmuje się porządek poznawczy w sposób zgodny z tymi ustaleniami współczesnej filozofii nauki, w których mowa jest o empirycznej nietestowalności twierdzeń filozoficznych, pierwszeństwie czynników teoretycznych, w tym filozoficznych względem obserwacji, niewspółmierności teorii naukowych oraz zgodności danego zbioru faktów z wieloma niezgodnymi ze sobą teoriami, co pociąga za sobą tezę, iż same dane empiryczne nie wystarczają do dokonania wyboru między konkurencyjnymi teoretyczno-filozoficznymi systemami przekonań. Za pomocą tak skonstruowanego MPA zostanie szczegółowo przedstawiona logiczna struktura ewolucjonizmu i kreacjonizmu oraz rozróżnienie i porównanie tych stanowisk pod względem empirycznego charakteru przyjmowanych przez nie twierdzeń. Artykuł ten nie ma na celu przedstawienia ostatecznego i pełnego sklasyfikowania omawianych twierdzeń, a jedynie zwrócenie uwagi na aspekty dyskutowanych stanowisk, które ujawniają się, gdy podda się je badaniom, dzieląc je pod względem ich empiryczności.

Ilustracją sporej części omawianych tu zagadnień są odwołania do prac Piotra Lenartowicza, który zabierał ważny głos w sporze kreacjonizmu z ewolucjonizmem. Lenartowicz jasno wyrażał także swoje stanowisko teoriopoznawcze, zdecydowanie odmienne od wymienionych wyżej ustaleń współczesnej filozofii nauki, a bazujące na Arystotelesowskiej filozofii poznania i wprost krytykował poglądy Feyerabenda w sprawie wiarygodności poznania zmysłowego (por. Lenartowicz 1986: 73-100). Przy pomocy
MPA można wskazać zarówno trafne spostrzeżenia Lenartowicza dotyczące światopoglądowo-filozoficznych czynników w nauce, jak i bardziej dyskusyjne przekonania o możliwości nauki, w tym naukowej obserwacji wolnej od wcześniejszych założeń filozoficznych i teoretycznych. Zastosowanie MPA pozwala łatwiej dostrzec założeniowy charakter twierdzeń filozoficzno-teologicznych Lenartowicza, które leżą u podstaw jego koncepcji przyrody ożywionej i roli Boga w świecie, w przeciwieństwie do głoszonego przez niego poglądu, iż teistyczne przekonania filozoficzno-teologiczne wynikać mają niejako z nieuprzedzonej obserwacji świata.

\section{Naturalizm naukowy a kreacjonizm i ewolucjonizm w sensie podstawowym}

Ewolucjonizm i kreacjonizm w sensie podstawowym i nieograniczonym jedynie do problemów biologicznych można scharakteryzować przez wskazanie ich stosunku do naturalizmu naukowego. Przez naturalizm naukowy proponuję tu rozumieć pogląd przyjmujący następujące twierdzenia: 1) naturalizm metafizyczny - istnieje jedynie materialny świat przyrody oraz jego wytwory; jeśli nawet istnieją jakieś nadnaturalne byty niezależne od materii, to nie wpływają w sposób empirycznie rozpoznawalny na procesy przyrodnicze; 2 ) scjentyzm - nauka zakładająca naturalizm jest najlepszym znanym sposobem na poznanie bardziej szczegółowych aspektów funkcjonowania świata. Naturalizm naukowy obejmuje też wszelkie filozoficzne założenia poszczególnych dziedzin i teorii naukowych oraz ich pozafilozoficzną treść, tj. przyjęte teorie naukowe oraz akceptowane w nauce twierdzenia o faktach.

Kreacjonizm w podstawowym sensie jest stanowiskiem niezgodnym z tak rozumianym naturalizmem i głosi, że za zmiennością w świecie kryje się działanie osobowego czynnika pozaprzyrodniczego. Przyjmuje, że stworzenie zostało już zakończone i od tego momentu nic zasadniczo nowego w świecie się nie pojawia. Odrzuca koncepcję naturalnego pokrewieństwa gatunków. Nie zgadza 
się też z szeregiem innych szczegółowych twierdzeń naturalizmu naukowego. Ewolucjonizm natomiast w pełni akceptuje naturalizm naukowy, a nawet stanowi jeden z jego najważniejszych składników. Głosi samoczynną zmienność świata, a w przypadku ewolucjonizmu biologicznego jako proces samoczynny tłumaczy powstanie i zmienność form życia. Przyjmuje więc transformizm gatunkowy i koncepcję pochodzenia wszystkich form żywych od jednego lub, ewentualnie, względnie niewielkiej liczby wspólnych przodków.

Takie przedstawienie podstawowych wersji kreacjonizmu i ewolucjonizmu pozwala zauważyć, że choć w rzeczywistości mają one swoich przedstawicieli, to jednak można też wskazać propozycje, w których poszczególne twierdzenia - przyporządkowane tu do opozycyjnych stanowisk - są łączone ze sobą, lub w ramach danego stanowiska nie akceptuje się części twierdzeń, które tu zostały mu przypisane. $\mathrm{Z}$ tego typu sytuacją mamy do czynienia na przykład w koncepcjach określanych jako ewolucjonizm teistyczny, ewolucjonizm deistyczny, teistyczny naturalizm. Ich zwolennicy często deklarują akceptację naukowego obrazu świata, chcąc jednocześnie pozostać wiernymi podstawowym prawdom religijnym. Podobne połączenie elementów obu stanowisk znajdujemy w kreacjonizmie progresywnym, który przyjmuje naukowe twierdzenia o wieku Ziemi, a nawet może akceptować ideę wspólnoty pochodzenia, ale jednocześnie przyjmuje bezpośrednie interwencyjne działanie Boga $\mathrm{w}$ procesie powstawania niektórych form żywych. Te różne odmiany stanowisk kreacjonistyczno-ewolucjonistycznych zostały już szczegółowo opisane w literaturze (por. Jodkowski 1998: 21-119; tenże 2007). Celem tego artykułu nie jest powielanie już wykonanej pracy, ale jedynie przyjrzenie się omawianym stanowiskom $\mathrm{z}$ punktu widzenia problemu empiryczności głoszonych w nich twierdzeń. Dotychczasowe analizy ujmują je bowiem głównie w ich aspekcie ontycznym, tak jak zostało to uczynione wyżej, czy społeczno-organizacyjnym. Przyjmując, że związek nauki z danymi empirycznymi stanowi jej kluczową cechę, to MPA - dzieląc twierdzenia opisowe pod względem stopnia empiryczności - pozwoli lepiej ocenić różne odmiany kreacjonizmu i ewolucjonizmu zarówno pod względem skuteczności godzenia obu wizji rozwoju przyrody, jak i pod kątem ich naukowego charakteru.

W dalszej części sam model poziomów analizy zostanie przedstawiony zwięźle. Bardziej szczegółowy opis wraz z dokładniejszym opisem założeń leżących u jego podstaw czytelnik znajdzie we wcześniej opublikowanych tekstach (por. Bylica 2016: 17-21, 32-63; tenże 2015; tenże 2012: 236-247). Poniższe jego przedstawienie jest jednak wystarczające dla uchwycenia specyfiki przyjętego w nim podejścia oraz adekwatnego ukazania rodzajów twierdzeń kreacjonizmu i ewolucjonizmu.

\section{Kreacjonizm i ewolucjonizm - Poziom I}

Poziom I (P1) - „najgłębszej” metafizyki zawiera twierdzenia zupełnie obojętne dla nauki w tym sensie, że nie wpływają na decyzję o akceptacji lub odrzuceniu jakiejkolwiek empirycznie sprawdzalnej teorii czy jakichkolwiek twierdzeń faktualnych. Obejmuje on więc zupełnie niezwiązane z doświadczeniem naukowym i najbardziej ogólne twierdzenia o samym bycie i jego atrybutach (np. „Byt jest, a niebytu nie ma”, „Byt jest wieczny i niezmienny”) czy nieempiryczne twierdzenia o relacji między Bogiem i światem (np. „Bóg podtrzymuje świat w istnieniu w każdym momencie"). Do tej kategorii należałyby też empirycznie neutralne twierdzenia o sferze nadnaturalnej, w tym o samym Bogu, jego naturze, jego „życiu wewnętrznym" itp.

Lenartowicz zauważał, że niektóre twierdzenia religijne mają taki właśnie empirycznie neutralny charakter:

O tajemnicy Trójcy Świętej nie dowiemy się z badań przyrodniczych, wcielenia Chrystusa, drugiej Osoby Trójcy Świętej nie potwierdzimy żadnym eksperymentem i nawet cuda nie 
mogłyby udowodnić na 100\% obecności Pana Jezusa w Najświętszym Sakramencie (...). To jest sfera sacrum, sfera wiary nadprzyrodzonej, sfera misterium stricte dictum, czyli tajemnicy przekraczającej aktualne pojmowanie człowieka. Bo to są wewnętrzne tajemnice życia Bożego (Koszteyn, Lenartowicz, 1997, za Web-01: 3).

Zredukowany do P1 kreacjonizm, który akceptowałby tezę o zmienności obserwowalnego świata przyrody, obejmującej także powstawanie jakościowo nowych form istnienia, przyjmowałby, że Bóg nieustannie stwarza świat w sposób empirycznie nierozpoznawalny, że stworzenie jest stałą relacją ontyczną między Bogiem, jako ontyczną podstawą świata, a obserwowalnym światem empirycznym. Byłby to więc kreacjonizm całkowicie nieempiryczny, żadne bowiem dane obserwacyjne ani nie potwierdzają, ani nie obalają tego typu twierdzeń. Ewolucjonizm na tym poziomie głosiłby, że zmienność jest atrybutem bytu materialnego, poza którym nic nie istnieje. Oba stanowiska sprowadzałyby się więc do najbardziej ogólnych, metafizycznych twierdzeń o samej naturze bytu, których żadne dane empiryczne nie są w stanie potwierdzić, ani nie są z nimi niezgodne.

Należy zwrócić uwagę, że obserwacja zmienności w przyrodzie nie rozstrzyga wcale o konieczności przyjęcia na tym poziomie twierdzenia o zmienności jako atrybucie bytu czy nawet o uznaniu za prawdziwe twierdzenia, że zmiana jest czymś realnym. Filozofia Eleatów jest tu dobrym przykładem.

\section{Kreacjonizm i ewolucjonizm - Poziom II}

Poziom II (P2) - metafizyki „płytszej” zawiera najbardziej ogólne twierdzenia o rzeczywistości empirycznej, jej najpowszechniejszych właściwościach, najogólniejszym porządku. O ile twierdzenia P1 można określić jako mające zerową empiryczność, to o P2 można powiedzieć, że ich empiryczność jest znikoma. Choć tak samo jak twierdzenia P1 nie są one empirycznie testowalne, to dotyczą świata obserwowanego. Niektóre z twierdzeń $\mathrm{P}_{2}$, jak twierdzenie o ogólnym racjonalnym porządku rzeczywistości, czy założenie naturalizmu wykluczające empirycznie rozpoznawalne działanie czynników nadnaturalnych w świecie, są ważnymi założeniami współczesnej nauki, a w pierwszym wypadku być może nauki w ogóle. Zmiana tego typu twierdzeń wiąże się ze zmianą rozumienia samej nauki.

Do tego poziomu należą na przykład metafizyczne rozważania o odwiecznej bezkierunkowości i chaotyczności leżące u podstaw wszelkich procesów obserwowanych w świecie przyrodniczym. Lenartowicz w ten sposób charakteryzował model przypisywany Kartezjuszowi:

W tym modelu chaotyczne, bezkierunkowe zderzenia cząstek materii nie tylko wyjaśniaja - jakoby - dosłownie Wszystko. Co więcej, te chaotyczne kolizje trwają od samych Początków kosmosu (o ile w ogóle miał on początek). Były od zawsze i dlatego nie trzeba tłumaczyć, skąd się one wzięły [podkreślenia i w pozostałych miejscach - PL] (Lenartowicz, 2008, za Web-02: 11).

Alternatywne ujęcia głosiłyby, że świat jako całość rządzony jest jakąś zasadą celowości, że to porządek, racjonalność i plan kryją się za obserwowaną zmiennością.

Nawet jeśli dla powstania takiej czy innej tak ogólnej wizji przyrody motyw stanowiły jakieś obserwacje, to nie czyni to twierdzeń tego typu twierdzeniami empirycznie testowalnymi. W przyrodzie można dostrzec zarówno fakty mogące inspirować do postrzegania jej jako uporządkowanej, jak i jako chaotycznej, okrutnej i łagodnej, szczodrej i niszczycielskiej itd. Przyczyny przyjęcia określonych twierdzeń typu $\mathrm{P}_{2}$, podobnie jak $\mathrm{P}_{1}$, muszą więc mieć charakter poza logiko-empiryczny. Dane empiryczne mogą tu służyć jedynie jako heurystyczne źródło inspiracji, które prowadzi do przyjęcia tych najogólniejszych twierdzeń w wyniku działania czynników pozaracjonalnych. Przyjęcie natomiast określonych twierdzeń P2 znacząco wpływa na to, jak postrzegamy świat jako całość, jakie twierdzenia 
niższych poziomów będziemy skłonni akceptować, w tym jak będziemy interpretowali poszczególne obserwowane fakty oraz jaki będzie nasz stosunek do nich w aspekcie aksjologicznym.

Kreacjonizm P2 głosiłby, że świat jako całość jest uporządkowany celowościowo oraz że jakieś nadnaturalne czynniki wpływały na rozwój Wszechświata w sposób ukryty lub jawny, ogólny lub specjalny, w tym specjalny łamiący prawa przyrody lub specjalny niełamiący praw przyrody (por. też Kilian 2017: 25-26). Ponieważ jest to twierdzenie empirycznie niesprawdzalne, to istnieje logiczna możliwość przyjmowania go wraz z dowolnymi empirycznymi twierdzeniami na temat powstania i historii życia na Ziemi, włącznie $\mathrm{z}$ empirycznymi twierdzeniami o transformizmie gatunkowym. Możliwe jest więc niesprzeczne wewnętrznie stanowisko, które można określić mianem kreacjoznimu ewolucjonistycznego, o ile kreacjonizm rozumie się w senesie metafizycznym, czyli nieempirycznym, zredukowanym do P1 lub $\mathrm{P}_{2}$, natomiast przyjmuje się ewolucjonizm $\mathrm{w}$ zakresie jedynie twierdzeń z niższych poziomów analizy, czyli o większym stopniu podatności na testowanie empiryczne.

Ewolucjonizm zredukowany do $\mathrm{P}_{2}$ mógłby głosić, że w odniesieniu do całości Wszechświata obserwowalne zmiany pozbawione są celowości i żadne nadnaturalne czynniki nie wpływały ani w sposób ukryty, ani jawny, ogólny ani specjalny w rozwój Wszechświata (por. też Kilian, 2017: 23-24). Taki metafizyczny ewolucjonizm $\mathrm{P}_{2}$ jest do pogodzenia z empirycznymi twierdzeniami o występowaniu celowości w poszczególnych sferach przyrody. Celowość obserwowana w zachowaniach organizmów żywych mogłaby być tłumaczona jako np. własność emergentna czy superwenientna powstała na mocy drugiego prawa materializmu dialektycznego. Takie szczególne stanowisko nie wyklucza metafizycznego twierdzenia $\mathrm{P}_{2}$, że ostatecznie jednak świat jako całość rozwija się w sposób nieukierunkowany. Taki ewolucjonizm byłby też zgodny z koncepcją, że życie na Ziemi i jego formy zostały stworzone przez istoty inteligentne. Powstanie tych istot, jak i wszelkich bytów cechujących się intencjonalnością, tłumaczyłby jednak metafizycznie jako efekt ślepej zmienności materii Wszechświata.

\section{Kreacjonizm i ewolucjonizm - Poziom III}

Poziom III ( $\left.\mathrm{P}_{3}\right)$ - ontologii przyrody - obejmuje bardziej szczegółowe twierdzenia filozoficzne o porządku przyrodniczym dotyczące poszczególnych sfer lub obszarów rzeczywistości empirycznej. Występują one jako filozoficzne założenia w ramach poszczególnych dziedzin nauki lub jako założenia teorii naukowych dotyczące ogólnej struktury, porządku, natury zjawisk i procesów badanych w ramach tych dziedzin czy wyjaśnianych przez określone teorie. Same te twierdzenia nie są testowalne empirycznie, a ich rewizji dokonuje się, gdy wymianie ulegają teorie czy dziedziny nauki, z którymi są związane, stąd można mówić, że mają większy stopień wrażliwości na dane empiryczne od twierdzeń filozoficznych z wyższych poziomów.

Kreacjonizm głosiłby na tym poziomie, że początek i rozwój życia są spowodowane przez czynniki nadnaturalne w sposób ukryty lub jawny, ogólny lub specjalny. Kreacjonista mógłby też przyjmować stanowisko witalizmu o ontycznej odmienności życia jako zjawiska nieredukowalnego do procesów i praw fizyki i chemii. Możliwe są stanowiska kreacjonistyczne mówiące o roli Boga w powstaniu życia i jego form i godzące tę koncepcję ze współczesną ontologią nauki $\left(\mathrm{P}_{3}\right)$. Propozycje takie odwołują się do akceptowanych w nauce twierdzeń ontologii przyrody o indeterminizmie procesów kwantowych czy nieliniowych układów dynamicznych. Przyjmuje się wtedy, że Bóg oddziaływał na proces ewolucji w sposób specjalny, ale niełamiący praw przyrody właśnie na poziomie kwantowym, lub wykorzystując nieliniowość układów i procesów chaotycznych, działał jak dziwny atraktor w momentach bifurkacji itp.

$\mathrm{Na}$ tym poziomie ewolucjonizm biologiczny odnosiłby mechanistyczne 
twierdzenia o braku celowości z $\mathrm{P}_{2}$ do zagadnienia rozwoju świata ożywionego. Przyjmowałby więc, że właściwym rodzajem wyjaśnień pochodzenia złożoności form żywych są wyjaśnienia mechanistyczne i funkcjonalistyczne. Wykluczałby jakiekolwiek kierowanie rozwojem życia na Ziemi przez czynniki nadnaturalne. Tu występowałoby stanowisko mechanicyzmu biologicznego, które głosi, że życie, procesy życiowe, wszelkie prawidłowości z nim związane sprowadzają się do procesów i praw fizycznych lub chemicznych.

Filozoficzne założenia nauki z $\mathrm{P}_{3}$ często związane są z odpowiednimi światopoglądowymi twierdzeniami P2. Prof. Lenartowicz wskazywał na zależność założeń współczesnej biologii od założeń naturalistycznych P1-2:

[Biologia] (...) działa często w „gorsecie” dość sztywnych (choć oczywiście historycznie zmiennych) schematów metodologicznych i nawet apriorycznych założeń o charakterze filozoficzno-światopoglądowym, narzucanych czasem społeczności badaczy przez tzw. elity intelektualne. W tej chwili, te schematy i te aprioryczne założenia, są formułowane w duchu monizmu materialistycznego, czego nie ukrywa zdecydowana większość biologów, głównie tych „filozofujących”, jak też i tych, którzy reflektują nad światopoglądowym fundamentem swojego "warsztatu pracy" (Lenartowicz 2008, za Web-02: 1-2).

Szczegółowym przejawem naturalistycznych twierdzeń $\mathrm{P}_{1}-\mathrm{P}_{2}$ jest w biologii dominacja antyteleologicznych twierdzeń $\mathrm{P}_{3}$ :

Nasze pokolenie wychowało się w epoce antyteleologizmu biologicznego. Celowe działanie jest $\mathrm{w}$ tej epoce dostrzegane jedynie tam, gdzie mamy do czynienia ze świadomą, refleksyjną działalnością człowieka. Wszelkie inne formy dynamiki biologicznej są od dziesięcioleci, ze względu na dogmatyczny charakter teorii ewolucji darwinowskiej, traktowane jako skutek pewnych fundamentalnych i zupełnie bezcelowych chaotycznych (w potocznym znaczeniu tego słowa) oddziaływań. Jeżeli niektóre te działania robią wrażenie celowych, selektywnych, racjonalnych, to i tak wynikają one, jakoby, z wcześniejszych wydarzeń, które były nieselektywne i bezcelowe. Program nauczania biologii antyteleologicznej wymaga, aby uczeń lub student doszedł do przekonania, że wszystkie formy życia powstały niegdyś dzięki:

a) bezkierunkowej, nieselektywnej dynamice materii mineralnej (abiogeneza) i zróżnicowały się potem w ogromny wachlarz różnorodnych form dzięki

b) bezkierunkowym, nieselektywnym uszkodzeniom (mutacjom) materialnych nośników informacji genetycznej (RNA lub DNA) oraz równie

c) bezkierunkowej, nieselektywnej „selekcji naturalnej" (Lenartowicz, 2008, za Web-o2: 3).

Lenartowicz dostrzegał paradoks wewnątrz biologii polegający na tym, że choć przyjmuje ona założenia mechanistyczne i redukcjonistyczne, to w znacznej części praktyka naukowa w biologii polega na stosowaniu założeń zupełnie przeciwnych. Redukcjonizm i mechanicyzm wydają się obowiązywać jedynie w obszarze wysoce spekulatywnych zagadnień związanych z początkiem życia lub jego form:

Paradoks współczesnej biologii polega na tym, że żaden szanujący się embriolog, biochemik czy fizjolog nie powie, że rozwojem żaby „rządzą” chaotyczne ruchy organelli lub komórek. Nikt nie powie, że cykl Krebsa to rezultat chaotycznych, bezładnych „kolizji” cząstek.

Chaos, przypadek, bezkierunkowość itd. pojawia się w stosunkowo bardzo ograniczonym wycinku współczesnej biologii. Przede wszystkim tam, gdzie mowa o (hipotetycznych) poczatkach $\dot{z} y c i a$, o ewolucji życia, o specjacji, czyli o powstawaniu nowych gatunków... itp. Wtedy najczęściej przywoływana jest bezcelowość, bezkierunkowość, bierność (podleganie wpływom), których empiryczną ilustracją („paradygmatem”) są ruchy Browna. Tymczasem prawdziwym przedmiotem badań biologii jest dynamika żywego osobnika, traktowanego jako niepodzielna całość. Tym zajmuje się ogromna większość biologów. Próby [...] rekonstrukcji „początków” to przedmiot spekulacji, których założenia nie pochodzą z obserwacji życia, lecz z filozofii materializmu, 
redukcjonizmu. [...] Tego rodzaju dociekaniami zajmują się tylko nieliczni spośród biologów (Lenartowicz 2008, za Web-02: 4).

Według Lenartowicza, naczelną kategorią biologiczną jest całość. Poniższy cytat dobrze ilustruje typ rozważań charakterystyczny dla $\mathrm{P}_{3}$ :

Wydaje mi się, że fundamentalnym pojęciem jest pojęcie całości biologicznej. Proces budowania gniazda przez wronę nie jest serią luźnych, krótkotrwałych wydarzeń, takich jak kłapnięcie dziobem, poruszenie skrzydłami, lub skurcz mięśni wroniego uda lub wroniej łydki. Proces budowania gniazda jest catościa.

[...] biolog musi operować pojęciami catościowymi, takimi jak proces odżywiania, proces rozmnażania, proces opiekowania się potomstwem, uktad nerwowy, uktad krwionośny... itp. (Lenartowicz 2008, za Web-02: 13).

Głównym przedmiotem badań Lenartowicza były właśnie całości biologiczne (por. Lenartowicz 2008: 30). Pojęcie całości odnosił on nie tylko do organizmów i funkcji biologicznych, które można badać empirycznie, lecz także rozumiał je szerzej - jako kategorię metafizyczną i epistemologiczną. Analizował je z punktu widzenia filozofii arystotelesowsko-tomistycznej, korzystając z założeń epistemologicznych oraz metafizycznych typu $\mathrm{P}_{2}$ i $\mathrm{P}_{1}$ :

Ambicją filozofowania w systemie arystotelesowsko-tomistycznym jest poznanie całości skutku w pierwszym rzędzie, poznanie przyczyn tej całości, wreszcie dotarcie do przyczyny pierwszej w łańcuchu przyczyn (Lenartowicz 2008: s. 30).

Takie poznanie miała cechować niearbitralność, prawdziwość, pewność i adekwatność (por. tamże: s. 30). Wydaje się, że Lenartowicz był jakby pod urokiem właśnie pojęcia całości oraz filozofii arystotelesowsko-tomistycznej i z nich czerpał szczególną inspirację.
Tymczasem we współczesnej nauce, za sprawą inspiracji płynącej z mechanistycznej filozofii ( $\left.\mathrm{P}_{2}\right)$ działania organizmów żywych, które poza człowiekiem miały być pozbawione duszy, tłumaczy się jako bezcelowe działania skupisk korpuskuł materii $\left(\mathrm{P}_{3}\right)$ :

To, co w maszynach mogło się wydawać „celowe", niczym, w swej istocie i genezie, nie różniło się (zdaniem Kartezjusza) od tworów czystego przypadku. Tak właśnie [...] została, jakoby, zasypana, zniwelowana przepaść pomiędzy wytworami materii mineralnej - np. płatkami śniegu, stalaktytami, stożkami wulkanicznymi a wytworami zwierząt - np. gniazdami ptaków, kopcami termitów, żeremiami i tamami bobrów, sieciami pająków. Gniazda ptaków zostały uznane za twory bezcelowe, podobnie jak zmieniające się kształty chmur (Lenartowicz 2008, za Web-02: 8).

Występująca w fizyce filozofia mechanistyczna przyjęta została także w biologii. W wyniku tego za właściwy przedmiot nauk uznane zostały jedynie byty materialne, tj. ciała, a właściwym wyjaśnieniem ich funkcjonowania jest odwołanie do praw fizyki i chemii. Celowość, myślenie, dusza nie są przedmiotami nauki, ale co najwyżej filozofii. Z punktu widzenia podejścia kartezjańskiego nie ma istotnej różnicy między dynamiką powstawania planet, koryt rzek, zjawisk atmosferycznych a dynamiką budowania gniazd lub rozwoju embrionów itp. (por. Lenartowicz 2008). Na podobną sytuację transferu idei zwracał uwagę Holton, gdy pisał, że themata odnoszące sukces w jednej dziedzinie nauki mogą przechodzić do innych nauk. Lenartowicz pisał o transferze mechanicyzmu kartezjańskiego z fizyki i chemii do biologii:

Gdy Kartezjusz zrównał dynamikę form żywych z dynamiką materii mineralnej, to fizyczno-chemiczne „musi” zostało bez odpowiedniej modyfikacji, bezrefleksyjnie przeniesione do biologii. W ten sposób zachowanie się form żywych zostało a priori nie tylko podporządkowane wpływom otoczenia, czyli zewnętrznym warunkom fizycznochemicznym. Owo „musi” zaczęło odtąd 
oznaczać, że w ciele istot żywych, fizycznochemiczna dynamika materii mineralnej, rzekomo "sama z siebie« zawęża się do prawidłowych procesów biochemiczno-fizjologicznych [...].

Filozofowie uwierzyli Kartezjuszowi i doszli do przekonania, że życie „musiało” kiedyś powstać, skoro zaistniały zewnętrzne warunki fizyczno-chemiczne konieczne dla jego istnienia. W tym sensie, skoro zaistniało powietrze, "musiały" (prędzej czy później) zaistnieć skrzydła ptaków, owadów i nietoperzy. Skoro zaistniała woda, to „musiaty” (prędzej czy później) zaistnieć płetwy, skrzela i... oczywiście całe ryby" (Lenartowicz, 2008, za Web-o2: 12).

Dla Lenartowicza oczywiste było, że istnieje celowość w funkcjonowaniu organizmów, że świadczy ona o istnieniu Stwórcy i przeczy naturalizmowi. Ale choć teleologia może być antropomorficzna, tj. odwołująca się do osobowego Stwórcy, to przecież nie musi. Celowość może być uznana za wytwór niecelowościowo rozwijającej się materii na zasadach emergencji, superweniencji czy na mocy praw materializmu dialektycznego. Poza tym można nieantropomorficznie mówić o celowym działaniu organów różnych organizmów, tj. w sensie funkcjonalistycznym. Dlatego ewolucjonista może nie być redukcjonistą, bo może przyjmować swoistość procesów życiowych, gdy już życie pojawi się jako własność emergentna materii nieożywionej. Zatem wbrew opinii Lenartowicza samo stwierdzenie celowości w świecie ożywionym nie musi pociągać za sobą przekonań antynaturalistycznych.

\section{Kreacjonizm i ewolucjonizm - Poziom IV}

Na poziom IV $\left(\mathrm{P}_{4}\right)$ - twierdzenia o regularnościach - składają się empirycznie testowalne twierdzenia opisujące regularności obserwowane w świecie. W nauce są to prawa i teorie naukowe mające zarówno postać zdań ściśle uniwersalnych, jak i praw oraz teorii o charakterze probabilistyczno-statystycznym. Twierdzenia z tego poziomu mogą być testowane przez „obserwację”, której wyniki opisywane są szczegółowymi zdaniami empirycznymi. Model poziomów analizy uwzględnia tezę o uteoretyzowaniu wszelkiej obserwacji rozumianej jako zależność znaczenia zdań empirycznych od czynników teoretycznych, w tym filozoficznych, i dlatego termin „obserwacja” w poprzednim zdaniu ujęty został w cudzysłów. Wydaje się, że Lenartowicz nie uwzględniał tej tezy w stopniu, który pozwoliłby mu zauważyć, że to wcześniej przyjęte twierdzenia z wyższych poziomów analizy wpływaja na interpretację i akceptację szczegółowych twierdzeń „obserwacyjnych”, których prawdziwość jawiła mu się jako oczywista. Dlatego, jak będzie pokazane dalej, z treści obserwacji poszczególnych faktów oraz obserwowanych regularności, które postrzegał jako oczywiste, uważał, że wyprowadza oczywiste konsekwencje filozoficzne, tj. antynaturalistyczne i teistyczne. MPA pozwala łatwo zauważyć, że w porządku poznania twierdzenia wyższych poziomów wyprzedzają te, które są umiejscowione niżej w tym modelu.

Trudno wskazać jakiekolwiek twierdzenia o regularnościach, które mógłby głosić kreacjonista uznający kreacjonistyczne twierdzenia $\mathrm{P}_{2}$, że Bóg dokonuje nadnaturalnych interwencji w świecie, a szczególnie $\mathrm{P}_{3}$, że rozwój życia jest wynikiem takich nadnaturalnych Boskich interwencji. Musiałby wskazać empirycznie sprawdzalne regularności, jakim podlegało Boskie interwencyjne stworzenie życia i jego form.

Inaczej jest w przypadku ewolucjonizmu jako stanowiska naturalistycznego w sensie $\mathrm{P}_{2}$ i $\mathrm{P}_{3}$ i jako nauki dążącej do poznania praw występujących w świecie. Ewolucjonizm dysponuje szeregiem twierdzeń o regularnościach, za pomocą których wyjaśnia zarówno pojawienie się życia na Ziemi, jak i jego dalszy rozwój. Wyjaśnienie powstania życia oraz jego poszczególnych form można ujmować jako wpisujące się w schemat wyjaśnienia historyczno-genetycznego, w którym nie wymaga się odwołania do praw, czyli twierdzeń o regularnościach. Ewolucjonizm głosi, że można wskazywać twierdzenia o regularnościach mówiące o procesach naturalnych, odpowiedzialnych za zachodzenie tych 
czy innych zdarzeń w historii życia. Odwołuje się do praw fizyki i chemii w biogenezie, gradualistycznym charakterze zmian ewolucyjnych, teorii przerywanej równowagi, specjacji, pojęć ewolucji allopatrycznej, sympatrycznej, roli doboru naturalnego i mutacji itp.

Teistyczny ewolucjonizm, odrzucający Boskie interwencje w procesie stworzenia, akceptuje tego typu ewolucjonistyczne twierdzenia o regularnościach, traktując je jako opis Boskiego sposobu stwarzania. Zgodnie z takim podejściem rolę Boga w tym procesie trafnie mają wyrażać wskazane wcześniej twierdzenia z wyższych metafizycznych poziomów analizy, mówiące o podtrzymywaniu świata w istnieniu, empirycznie niewykrywalnej immanentnej obecności w przyrodzie, o Bogu jako podstawie ogólnej racjonalności porządku świata. Ponieważ mówi się tu o jakiejś roli Boga, bez którego stworzenie by się nie dokonało, to można stanowisko to określić także mianem kreacjonizmu, ale nieinterwencjonistycznego.

W rzeczywistości, w ramach ewolucjonizmu trwają dyskusje odnośnie mechanizmu ewolucji, czyli twierdzeń o regularnościach mających wyjaśniać powstawanie nowych form życia. Szczególnie dotyczą one makroewolucji, czyli powstawania nowych form ponad poziomem gatunkowym, np. na poziomie nowych planów budowy ciał. W filozofii nauki natomiast zgłaszane są wątpliwości, czy ewolucjonistyczne twierdzenia o regularnościach odnoszone do makroewolucji mają charakter empiryczny. Uwagi takie zgłaszał między innymi Karl Rajmund Popper:

[...] darwinizm nie jest sprawdzalną teorią naukową, lecz metafizycznym programem badawczym - możliwą strukturą pojęciową dla sprawdzalnych teorii naukowych (Popper 1997: 235).

\section{Podobnie pisał Jodkowski:}

Teoria ewolucji jest mianowicie metafizyką. Pogląd taki jest nieoczywisty głównie dlatego, że wszyscy wiemy, jak wiele empirycznych badań ewolucjoniści prowadzili i prowadzą, oraz jak wiele z tych badań zakończyło się sukcesem (Jodkowski 2009: 18).

Zasada doboru naturalnego ma, jak się okazuje, metafizyczny (niefalsyfikowalny empirycznie) charakter, ale nie ma w tym niczego złego. Jest ona bowiem metafizycznym programem badawczym, generującym tysiące już empirycznych podteorii. I to w tych podteoriach mieszczą się wszystkie empiryczne osiągnięcia współczesnego ewolucjonizmu. Nie byłoby ich, gdyby nie ów metafizyczny program badawczy. Po raz kolejny należy porzucić pozytywistyczne przesądy na temat relacji wzajemnych filozofii i nauki (tamże, 19-20).

Jeśli zgodzić się z tymi ujęciami, to najważniejsze twierdzenie ewolucjonizmu o roli doboru naturalnego należałoby traktować jako twierdzenie filozoficzne $\mathrm{P}_{3}$. Mimo tych wątpliwości obaj zwracają uwagę, że nawet jeśli traktować centralne twierdzenie ewolucjonizmu jako metafizyczny program badawczy, to generuje on teorie, czyli twierdzenia o regularnościach, które są już empirycznie testowalne.

Do ogólnych twierdzeń empirycznych w wizji przyrody według Lenartowicza można zaliczyć twierdzenie o selektywności w dynamice układów żywych. Lenartowicz odwoływał się do tego twierdzenia o regularnościach jako wyrażającego istotną cechę organizmów żywych odróżniającą je od bytów nieożywionych. Z tego twierdzenia P4 wyprowadzał wnioski odnośnie twierdzeń z wyższych poziomów analizy. Pisał, że rozpoznanie selektywności prowadzi do przyjęcia tezy o organizmach żywych jako całościach $\left(\mathrm{P}_{3}\right)$, jako posiadających duszę $\left(\mathrm{P}_{3}\right)$, prowadzi do stwierdzenia nieadekwatności mechanistycznego wyjaśnienia ich powstawania $\left(\mathrm{P}_{3}\right)$, do uznania istnienia Stwórcy życia $\left(\mathrm{P}_{3}\right)$, a nawet Boga w ogóle ( $\left.\mathrm{P}_{1}\right)$. Mamy tu więc też ilustrację jego przekonania, że twierdzenia niższego rzędu, w tym przypadku P4, służą rozstrzyganiu o słuszności twierdzeń z wyższych poziomów:

Zakwestionowanie selektywności tak oczywistej w dynamice maszyn i dynamikach 
„maszynotwórczych” było - jak sądzę - koniecznym etapem próby ukrycia, że odrzucenie Boga jest decyzją arbitralną, irracjonalną (Lenartowicz 2008, za Web-02: 13).

\section{Kreacjonizm i ewolucjonizm - Poziom V}

Do poziomu V $\left(\mathrm{P}_{5}\right)$ - twierdzeń „obserwacyjnych" - należą zdania szczegółowe, zdania empiryczne, które opisują zdarzenia mające miejsce w określonym miejscu i czasie.

Kreacjonizm interwencjonistyczny głosiłby tu twierdzenia o tym, kiedy i w jakim miejscu na Ziemi powstało życie lub poszczególne jego formy za sprawą Boskiej interwencji.

Ewolucjonizm głosiłby, gdzie i kiedy powstało życie i poszczególne jego formy.

Kreacjonizm nieinterwencjonistyczny mógłby uznawać twierdzenia empiryczne ewolucjonizmu naturalistycznego, jednak byłby kreacjonizmem jedynie o tyle, o ile przyjmowałby, że te szczegółowe twierdzenia opisują to, co nie miałoby miejsca, gdyby nie ten czy inny rodzaj udziału Boga w procesie zmienności form materii. Najsłabsza forma takiego kreacjonizmu sprowadzałaby się do metafizycznych twierdzeń, że rola Boga ograniczała się do podtrzymywania tego procesu $\mathrm{w}$ istnieniu lub do jakiejś niewpływającej na kierunek zmian obecności Boga w tym procesie. Pośrednie formy kreacjonizmu nieinterwencjonistycznego uznawałyby, że Bóg ukierunkowałby rozwój materii w sposób deistyczny, albo jakoś tajemniczo wpływał na jej rozwój w trakcie jego trwania.

Lenartowicz wykorzystał odwołania do danych empirycznych $\left(\mathrm{P}_{5}\right)$ dla rozstrzygnięcia ogólnego twierdzenia o jedności plemion człowieka ( $\left.\mathrm{P}_{4}\right)$ :

Książka dotyczy pytania o to, na czym polega jedność plemion człowieka, z jednej strony, i pytania o relację tych wszystkich plemion wobec małp człekokształtnych. Dotyczy też pytania o starożytność człowieczeństwa. (...)
(...) szczątki rozpoznawalne jako pozostałości po człowiekowatych (bipedalizm, mastykacja typu ludzkiego) powinny być uznane za szczątki prawdziwego człowieka, czyli Homo sapiens. Zmiany rozmiarów i proporcji ciała jakie się w materiale tych szczątków obserwuje, nie uzasadniają hipotezy istnienia formy „przedrozumnej". Nie istnieją bowiem - jak się zdaje wiarygodne, przekonywające dane empiryczne za istnieniem „przedrozumnych” form człowiekowatych. W proponowanej tutaj hipotezie przyczyna pewnych zmian morfologii wynikała $z$ wewnętrznego, wewnątrzgatunkowego potencjału adaptacyjnego gatunku Homo sapiens. Przepaść pomiędzy plemionami ludzkimi, a populacjami małp wydaje się tak samo głęboka w pliocenie, jak głęboką była w późnym plejstocenie. (...)

Powyższa hipoteza przeciwstawia się przyjętej w sferach akademickich hipotezie darwinowskiej, czyli hipotezie stopniowej ewolucji istoty podobnej do małpy w istotę bardziej przypominającą człowieka" (Lenartowicz 2010: 15).

Pod pewnym względem zbieżnie $\mathrm{z}$ ideą przyjętą w MPA, Lenartowicz zauważał, że po przyjęciu w biologii określonych założeń filozoficznych, wpływają one na empiryczny obszar tej nauki:

Biologia, jako nauka - pod wpływem takiego »ducha epoki« - może faworyzować pewne obserwacje pobrane z magazynu wiedzy przyrodniczej, a inne takie obserwacje chować pod korcem. Biologia jako nauka przyjmuje pewne interpretacje jako wiarygodne, a inne uznaje za bezwartościowe, mimo że ta ocena może się z upływem czasu zmieniać i to bardzo radykalnie (Lenartowicz 2008 za Web-02: 2).

Jeśli więc można mówić, że Lenartowicz przyjmował tezę o uteoretyzowaniu obserwacji, to powyższy fragment ilustruje jedynie, że przyjmował on dość słabą odmianę tej tezy, głoszącą że teoria wpływa na to, jakie obserwacje będą uznawane ze ważne. Prawdopodobnie nie zgodziłby się, że to wcześniej przyjęte teorie wpływają na znaczenia zdań empirycznych i że każda obserwacja jest w ten sposób uteoretyzowana. 
Pisał bowiem o oczywistości tego co jawi się w obserwacji, co można dostrzec w świecie ożywionym niezależnie od poziomu wykształcenia, kompetencji poznawczych, czyli wcześniej przyjętych teorii. Dodatkowo Lenartowicz uważał tė̇, że poznanie danych empirycznych prowadzi do rozstrzygnięć w zakresie ontologii biologii, a nawet metafizycznych twierdzeń zaliczanych w MPA do najwyższych poziomów. MPA pozwala zauważyć jednak, że za "oczywistością", „spontanicznością poznania intelektualnego" i „dostrzeganiem” prawdziwości różnych twierdzeń, kryje się niezależne od danych empirycznych wcześniejsze przyjęcie określonych twierdzeń metafizycznych. Ponieważ są one często przyjmowane milcząco, może to sprawiać iluzję, iż wcale one nie są wcześniejsze, że ich prawdziwość wynika jakoś z samych faktów. Lenartowicz wydaje się wyrażać tę iluzję, gdy pisze o tym, co można dostrzec obserwując świat:

Niezależnie od etapu rozwoju osobnik jest jednością, czymś oczywiście aktywnym, zdolnym przeciwstawiać się (w pewnych granicach) wpływom otoczenia. Aby tę jedność dostrzec, trzeba kolejno:

1. Dostrzec selektywność i jedność w dynamice maszyny.

2. Dostrzec selektywność w strukturach maszyny.

3. Dostrzec selektywność i jedność w procesach budowania struktur maszyny.

4. Dostrzec konieczność istnienia czynnika wymuszającego ową selektywność i jedność - czyli dostrzec istnienie „duszy” (konkretnego osobnika, konkretnej formy żywej).

5. Dostrzec konieczność istnienia źródta owych "dusz" - Boga Stwórcy.

Tych pięć etapów poznania intelektualnego, dokonuje się prawie »automatycznie«, prawie lub dosłownie podświadomie. Każdy człowiek, niezależnie od wykształcenia, od wczesnych lat swego istnienia może dostrzec tę selektywność i te konieczności „metafizyczne”.

Spontaniczność poznania intelektualnego może tłumaczyć, dlaczego wielu przyrodników, mimo braku przygotowania filozoficznego błyskawicznie wiąże teleologizm z przekonaniem o istnieniu Boga, Stwórcy (Lenartowicz 2008 za Web-02: 10-11).

Na dowód tej oczywistości czy „naoczności" antynaturalistycznych wniosków z empirycznych przesłanek Lenartowicz przytaczał wypowiedzi samych uczonych, w których wprost stwierdzali, że przyjmują naturalistyczne twierdzenia o powstaniu życia wbrew temu, co wskazują badania empiryczne. Przytacza na przykład wypowiedź Georga Walda, biochemika i laureata $\mathrm{Na}$ grody Nobla w zakresie medycyny:

Wystarczy (...) rozważyć ogrom (...) zadania wyewoluowania pierwotnego życia z materii nieorganicznej, by przyznać, że samoistne wytworzenie się żywego organizmu jest niemożliwe. (...) [Jednak - dop. P.L.] naukowiec nie ma innego wyboru, jak tylko podejść do problemu genezy życia poprzez hipotezę samoistnego wytworzenia się (...) Nie chcę uwierzyć w Boga. Dlatego też wolę wierzyć w to, o czym wiem, iż jest naukowo niemożliwe: [czyli w - dop. P.L.] samoistne wytworzenie się prowadzące do ewolucji (Wald 1954: 46; cyt. za Lenartowicz 2008, za Web-o2: 11).

Lenartowicz komentował wypowiedź Walda, stwierdzając, że ten:

[...] świadomie wybiera „naukowo niemożliwą" teorię samoistnego powstania życia - bo woli wiarę $\mathrm{w}$ to co naukowo niemożliwe, niż wiarę w Boga Stwórcę. To jest postawa ateistyczna. Nie jest to ateizm wynikający z empirii, ale ateizm $\mathrm{z}$ „wyboru” apriorycznych założeń metodologicznych lub światopoglądowo-filozoficznych, lekceważący empirię biologiczną (Lenartowicz 2008, za Web-02: 14)

Zgodnie z ideą „odgórnego” kierunku porządku poznawczego przedstawianą za pomocą MPA, przyjęte teorie wraz z założeniami wyższego rzędu są ściśle związane z obserwacjami, niekiedy w ten sposób, że prowadzą do obserwacji, których przy przyjęciu innych teorii nikt by nie oczekiwał, ani nie przeprowadził. Na tej zasadzie na 
przykład nikt nie oczekiwałby ani dążyłby do zaobserwowania paralaksy gwiezdnej, gdyby wcześniej nie zakładał, że Ziemia krąży wokół Słońca. Lenartowicz pisze o przykładzie jeszcze silniejszej zależności związanej z wyjaśnieniem procesu zapłodnienia:

Od pierwszej połowy XVII wieku - przez ok. 150 lat - biologia tkwiła w epoce preformacji (anty-embriologizmu). Wszelkie obserwacje dotyczące procesów embriogenezy były wtedy jakby zapomniane, a na ich miejsce pojawiały się niekiedy „obserwacje” tak niesłychane, jak np. dostrzeganie w plemniku ukształtowanego anatomicznie ciała ludzkiego (Lenartowicz 2008, za Web-02: 2).

Lenartowicz zauważał więc jakąś rolę założeń teoretycznych w badaniach empirycznych, ale jednocześnie twierdził, że obserwacje wyrażane twierdzeniami $\mathrm{P}_{5}$ rozstrzygają o prawdziwości twierdzeń filozoficznych $\mathrm{P}_{3}$ w obszarze ontologii biologii. Pisał, że dane empiryczne przeczą redukcjonizmowi w bio$\operatorname{logii}\left(\mathrm{P}_{3}\right)$. Przyjęcie redukcjonizmu w odniesieniu do zjawisk życia wiąże się według niego z:

1. lekceważeniem danych empirycznych,

2. lekceważeniem pytań, które powinny być motorem badań przyrodniczych,

3. bezpodstawnym uogólnianiem fragmentów wiedzy (zjawisko ruchów Browna), by uczynić z nich wytrych do „zrozumienia” Przyrody tak mineralnej, jak i ożywionej” (Lenartowicz 2008, za Web-o2: 16).

Lenartowicz pisał tak, bowiem wierzył w „oczywistość” faktów, być może nawet w „nagie” fakty, które mówią same za siebie. Dlaczego jednak uogólnienia ze zjawiska ruchów Browna są bezpodstawne, a z innych zjawisk trafne? Wybór nie może być podyktowany przez same fakty, skoro one są różnego rodzaju i należy dopiero zdecydować, który fakt uznamy za wzorcowy. Dlatego wybór faktów wzorcowych musi być dyktowany wcześniejszymi założeniami.

Lenartowicz zauważał jednak, że można przyjmować różne twierdzenia wbrew faktom: „Nawet oczywiste fakty nie zmusza nas do zmiany stanowiska. Na tym polega nasza anarchiczna wolność intelektualna" (Lenartowicz 2008, za Web-02: 16). Jego zdaniem, za sprawą tej anarchistycznej wolności intelektualnej biolodzy mechanicyści i redukcjoniści trwają przy swoich stanowiskach, wbrew oczywistym faktom.

\section{Wnioski}

MPA pozwala pokazać, że rodzaje twierdzeń $\mathrm{P}_{2}-\mathrm{P}_{5}$ są ważne zarówno dla nauki, jak i religii, natomiast twierdzenia $\mathrm{P} 1$ nie występują $\mathrm{w}$ nauce $\mathrm{w}$ tym sensie, że są neutralne względem ogólnych oraz szczegółowych reguł metodologicznych oraz wyników treściowych nauki. Twierdzenia kreacjonizmu i ewolucjonizmu różnią się ze względu na stopień ich empiryczności. Niektóre z nich nie są wcale są empiryczne, natomiast ze względu na uprzedniość czynników teoretyczno-filozoficznych w porządku poznawczym żadne $\mathrm{z}$ tych twierdzeń nie jest testowalne przez nieuprzedzoną niczym obserwację. Same dane empiryczne, czyli twierdzenia z najniższego poziomu analizy, nie są w stanie rozstrzygać z mocą logicznej pewności o prawdziwości twierdzeń z filozoficznych poziomów analizy. Wrażenie, że jest inaczej, któremu ulegał Lenartowicz i któremu często ulegają zarówno zwolennicy arystotelesowsko-tomistycznej teorii poznania i metafizyki jak i zwolennicy naturalizmu czy innych systemów filozoficznych, jest wynikiem swoistego zauroczenia tą określoną filozofią. Teistyczne wnioski z obserwacji, o których pisał Lenartowicz, są więc raczej wynikiem wcześniejszych założeń, a nie logicznymi konsekwencjami z danych empirycznych. MPA pokazuje jednak jedynie relacje logiczne między poszczególnymi rodzajami twierdzeń, a nie rozstrzyga o ich wartości logicznej. Nie wyklucza więc, że metafizyka, pod urokiem której był Lenartowicz, odpowiada prawdzie bytu samego, pokazuje jednak, że związek między obserwacją a teoriami naukowymi i filozofią nie jest tak jednoznaczny, jak przyjmuje indukcjonistyczny model poznania. 


\section{Bibliografia}

Bylica P., 2012, Zarys modelu poziomów analizy $w$ badaniach relacji nauki i religii, Filozoficzne Aspekty Genezy, t. 9, 221-253.

Bylica P., 2015, Levels of Analysis in Philosophy, Religion, and Science, Zygon: Journal of Religion and Science, vol. 50, no. 2 (June 2015), 304-328.

Bylica P., 2016, Wspótczesny teizm naturalistyczny z punktu widzenia modelu poziomów analizy. Problem dziatania sfery nadnaturalnej w przyrodzie, Biblioteka Filozoficznych Aspektów Genezy, t. 7, Instytut Filozofii Uniwersytetu Zielonogórskiego, Zielona Góra.

Jodkowski K., 1998, Metodologiczne aspekty kontrowersji ewolucjonizm-kreacjonizm, Realizm. Racjonalność. Relatywizm, t. 35, Wyd. UMCS, Lublin.

Jodkowski K., 2007, Spór ewolucjonizmu z kreacjonizmem. Podstawowe pojęcia i poglądy, Biblioteka Filozoficznych Aspektów Genezy, t. 1, Wydawnictwo Megas, Warszawa.

Jodkowski K., 2009, Darwinowska teoria ewolucji jako teoria filozoficzna, w: Konstańczak S. i Turowski T. (red.), Filozofia jako mądrość bycia, Oficyna Wydawnicza Uniwersytetu Zielonogórskiego, Zielona Góra, 17-23.

Kilian K.J., 2017, Geneza idei epistemicznych uktadów odniesienia i ich odmiany, Filozoficzne Aspekty Genezy, t. 14, s. 137-19o.

Koszteyn J., Lenartowicz P. SJ, Kijas Z., 1997, Czy nauka mówi o Bogu? (Z dr Jolantą Koszteyn i z prof. Piotrem Lenartowiczem SJ rozmawia o. Z. Kijas OFMConv), w: Kijas Z. OFMConv (red.), Mówić o Bogu, t. 1, Stowarzyszenie Civitas Christiana w Krakowie, Wyd. OO. Franciszkanów „Bratni Zew", Kraków, 89-114.

Lenartowicz P. SJ, 1986, Wiarygodność twierdzeń przyrodniczych (Arystoteles contra Feyerabend), w: Janik J.A., Lenartowicz P. SJ (red.), Nauka - Religia - Dzieje, III Seminarium Interdyscyplinarne $w$ Castel Gandolfo 6-9 sierpnia 1984, Wydział Filozoficzny Towarzystwa Jezusowego, Kraków, 73-10o.

Lenartowicz P. SJ 2008, Celowość dynamiki biologicznej a bezkierunkowość $w$ ewolucjonizmie darwinowskim, w: Maryniarczyk A., Stępień K., Gondek P. (red.), Spór o cel. Problematyka celu i celowościowego wyjaśniania, Zadania Współczesnej Metafizyki, t. 10, Polskie Towarzystwo Tomasza z Akwinu, Lublin, s. 317-344.

Lenartowicz P. SJ, 2008, Elementy filozofii zjawiska biologicznego, Biblioteka Filozoficznych Aspektów Genezy, t. 5, Wyd. Megas, Warszawa.

Lenartowicz P. SJ, 2010, Ludy czy małpoludy, Wyższa Szkoła Filozoficzno-Pedagogiczna Ignatianum, Kraków.

Popper K.R., 1997, Nieustanne poszukiwania: autobiografia intelektualna, Znak, Kraków.

Wald G., 1954, The origin of life, Scientific American, vol. 191, 44-53.

(Web-o1) Koszteyn J., Lenartowicz P. SJ, Kijas Z. OFMConv, http://lenartowicz.jezuici.pl/wpcontent/uploads/2011/o9/50-O-wierze-z-Kijasem-19971.pdf.

(Web-o2) Lenartowicz P. JS, http://lenartowicz.jezuici.pl/wp-content/uploads/2011/o9/17-Celowoscdynamiki-20o8.pdf.

\title{
Creationism and evolutionism from the model of levels of analysis perspective - with reference to fragments of writings by Piotr Lenartowicz SJ
}

\begin{abstract}
The model of levels of analysis (MLA) distinguishes among five types of descriptive statements on reality depending on their level of empirical testability. The aim of this article is to use the MLA in categorising variants of creationism and evolutionism and the statements these contain. This will allow one to evaluate how the distinguished variants fit in in terms of the attempts at bringing together science and religion and the problem of scientific character of respective statements found within creationism or evolutionism. The article makes a number of references to Piotr Lenartowicz's claims, whose opinions are considered as important in the debate on the character of the described variants. In terms of Lenartowicz's views, the use of MLA will allow distinguishing between valid claims regarding the philosophical and social factors in science and the hardly tenable ones, when one takes into account what modern philosophy of science has to say on the relations between observation, theory and philosophical factors. In particular, MLA makes it easier to notice that the philosophical and theological views of theistic character that
\end{abstract}


supposedly follow from an unbiased observation of the world are, in fact, used as assumptions that influence what one views as facts.

\section{Keywords}

creationism, evolutionism, levels of analysis, Piotr Lenartowicz SJ 